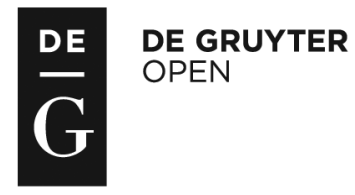

Administration, vol. 65, no. 2 (2017), pp. 37-57

doi: 10.1515/admin-2017-0014

\title{
Dáil reforms since 2011: Pathway to power for the 'puny' parliament?
}

\author{
Catherine Lynch \\ Oireachtas Library and Research Service \\ Eoin O'Malley \\ Dublin City University \\ Theresa Reidy \\ University College Cork \\ David M. Farrell \\ University College Dublin \\ Jane Suiter \\ Dublin City University
}

\begin{abstract}
We know that the Dáil is dominated by the government. From 2010 to 2016 there was a clamour for change, which ultimately led to significant reforms of the Oireachtas, and specifically the Dáil. In this article we show that the basis for the weakness of the Dáil was the government's control of the legislative agenda. This article tracks the changes that were made, and we make an early assessment of them. However, firm conclusions are difficult to draw because of the extent to which the strengthening of the Dáil is a function of the weak position of the current minority government.
\end{abstract}

Keywords: Dáil reform, parliament, agenda setting, agenda control, Ceann Comhairle 


\section{Introduction}

Endemic problems in the Irish political system were brought into sharp focus by the economic crisis from 2008. Long-rehearsed arguments about the weaknesses of parliament in Ireland came to the fore quickly and formed an important part of the political reform debate, which was especially prevalent during the 2011 general election. Political reform proposals were produced by all of the political parties, with many advocating extensive reforms of the Dáil. The promised reforms were slow to materialise and although political reform, and specifically Dáil reform, had drifted substantially down the agenda in the months leading up to the 2016 general election, the outgoing government enacted a number of discrete, but potentially significant, changes to the operation of business in parliament.

Internationally, the processes of how, and reasons why, parliamentary procedures are reformed are subject to renewed interest (Sieberer et al., 2011). In Ireland political fragmentation and a minority government after the 2016 election provided the impetus for further attention to Dáil reform. A Sub-Committee on Dáil Reform was established and its final report made a series of recommendations, many of which have been implemented. This article contributes to this growing literature and is guided by two key questions:

i. What were the critical weaknesses of the Dáil?

ii. How have the reforms implemented over the last two Dáil terms ameliorated the weakness of parliament in Ireland?

In the next section we provide a robust diagnosis of the weaknesses of the Dáil, drawing from the international literature on parliaments. The focus is on agenda-setting powers and the selection procedure for the speaker (chair) of parliament (Ceann Comhairle). The classification of agenda-setting powers by Tsebelis \& Rasch (2011) is used to structure the discussion. The article then traces the evolution of the debate on Dáil reform during the economic crisis from 2008. The political context is essential to understanding why long-mooted reforms were eventually implemented. MacCarthaigh \& Manning (2010, p. 31) point out that changes in the conduct of Dáil business were 'slow to come and usually grudgingly conceded'. This section provides the background to the changes that created a viable environment in which parliamentary reform could be enacted. The final section documents the reforms implemented during each Dáil 
term and provides an evaluation of how the reforms have changed parliamentary business.

\section{A comparative assessment of the basis of the 'puny' parliament}

Though much of the popular attention on the failings of the Irish political system focuses on the electoral system and the whip system, research and public analysis of parliament in Ireland have tended to focus on the dominance of the executive over parliament: in essence the Dáil is unable to adequately fulfil many of the functions expected of a national parliament (O'Malley, 2011). These functions include powers of appointment and dismissal, the power to scrutinise the executive and the power to make laws. In addition to their specific powers, parliaments also fulfil other important functions, including representation and legitimacy. The analysis proceeds from here by focusing on the idea of the Dáil as a weak parliament.

Parliamentary agenda control can be regarded as the single most important institutional determinant of parliamentary power (Koss, 2015). Here we operationalise this as the ability of parliament to choose its own chairperson and to set its own agenda. The role of parliament in the legislative process is dealt with more substantively by Lynch, in this issue, in an article which is focused on reforms of the committee system.

\section{The Ceann Comhairle}

Parliaments across Europe elect their chair by secret ballot, thus giving parliamentarians more scope to select a chair of their preference. In the UK a secret ballot for the Speaker of Parliament has been in place for a number of years and this is also the case in other Westminsterstyle parliaments, including Canada and Australia. A secret ballot reinforces the idea that the speaker is a wholly independent office holder, with no political obligations to the government of the day.

In addition, there is an argument that the Ceann Comhairle, as chair of the house, should be as neutral as possible and command the respect of as many members as possible. Internationally, experience has shown that the more difficult it is to become presiding officer, the more neutral the person so selected will be. The idea is that the higher the threshold for election, the more the individual selected will be a product of the whole house, as distinct from being the product of a faction or coalition of factions within the chamber. 


\section{Agenda setting}

Agenda-setting powers include institutional structures (the rules and procedures which regulate the interaction between the legislature and the executive) and positional discretion, which is the centrality of the formal agenda setter (which relates to the policy positions of the formal agenda setter compared to other legislators, including the extent to which other legislators are broadly united or fragmented (Tsebelis \& Rasch, 2011, p. 1)).

Institutional sources of agenda-setting power are rules which determine what set of proposed legislation will be considered by parliament, how it is considered, including the time given to debates, and the manner in which decisions are taken. Positive agenda-setting powers ensure consideration of proposals; negative powers prevent or restrict consideration of proposals (Krehbiel, 1992; Tsebelis \& Rasch, 2011, p. 5). While governments tend to be agenda setters in parliament, the extent of their agenda-setting powers varies across parliamentary democracies; the weaker its agenda-setting powers, the more influence we expect parliament to have over policy and legislative outcomes.

Agenda control can be either centralised or decentralised (Koss, 2015 , p. 1,064). If we consider a spectrum depicting fully centralised to fully decentralised, agenda-setting power helps to demonstrate how instruments work to either give or remove choices from certain actors. Where agenda-setting power is fully centralised, only one actor (the agenda setter) can make proposals or propose amendments to proposals; that same agenda setter decides when to propose them to parliament and the length of time for which parliament will consider them; parliament has the power to either approve or reject (but cannot amend) the proposal (closed rule). On the other hand, where agendasetting powers are fully decentralised, parliament decides what business is on the agenda, the right to propose legislation or amendments lies with individual members, all members may table amendments to proposals, and voting takes place on the bill and amended versions of the bill. In the first case, the agenda setter - the government - has almost full control over policy outcomes; government makes proposals and if, for example, parliament does not like one aspect of its proposals, it must reject the full proposal. At the other end of the spectrum, no actor has agenda-setting power and it may be difficult for any proposals to be approved by parliament. Most parliaments therefore lie somewhere in the middle of this spectrum; the Dáil has always been placed closer to the 'centralised' end (see 
Döring, 1995). Indeed, Garritzmann (2017), in a study of opposition power in parliamentary democracies, located Ireland at zero on a scale of zero to one, where for comparative purposes Austria and Belgium were both ranked at 0.86 .

Tsebelis \& Rasch (2011, p. 6) group instruments of agenda-setting power into five categories:

i. timetable and schedule power;

ii. proposal rights and gatekeeping rules;

iii. closed and restrictive rules;

iv. expansive rules and sequencing rules;

v. vote counting and voting order rules.

Using this classification, we can explore their impacts in more specific detail. Timetable and schedule control refers to who holds the power to schedule issues and control the legislature's timetable. The actor who fixes the schedule of debates has the power to prioritise certain proposals over others. Döring (1995) ranked parliaments on a spectrum from 'very strong government control' to less and less government control of the right to set the plenary agenda. At one end, government sets the plenary agenda, including the proposals on the agenda, the order in which business is taken and the time allocated to debates. At the other extreme, parliament, by a vote or some other mechanism, sets the agenda and government has no special prerogatives. In many parliaments the plenary agenda is set by a presidium or a business committee; where this is the case, the extent of government control depends on the decision rule in this presidium.

The decision rule can include: the government having an automatic weighted majority on the decision-making body; decision by a formal vote; decision made by unanimous agreement and, if this cannot be achieved, by the speaker. Finally, where a government has the right, $e x$ post, to correct the decision of the presidium, it has greater control over the agenda; where this is explicitly ruled out, government control is diminished. Döring (1995, p. 224) placed countries on a seven-point spectrum from more government control to less government control (see Table 1), and listed Ireland and the UK as the two most centralised West European parliaments, while the Netherlands occupied the position of least centralised parliament. The ensuing decades have witnessed considerable parliamentary reform and later in this article we evaluate how far recent reforms have changed the position of the Dáil on this spectrum. 


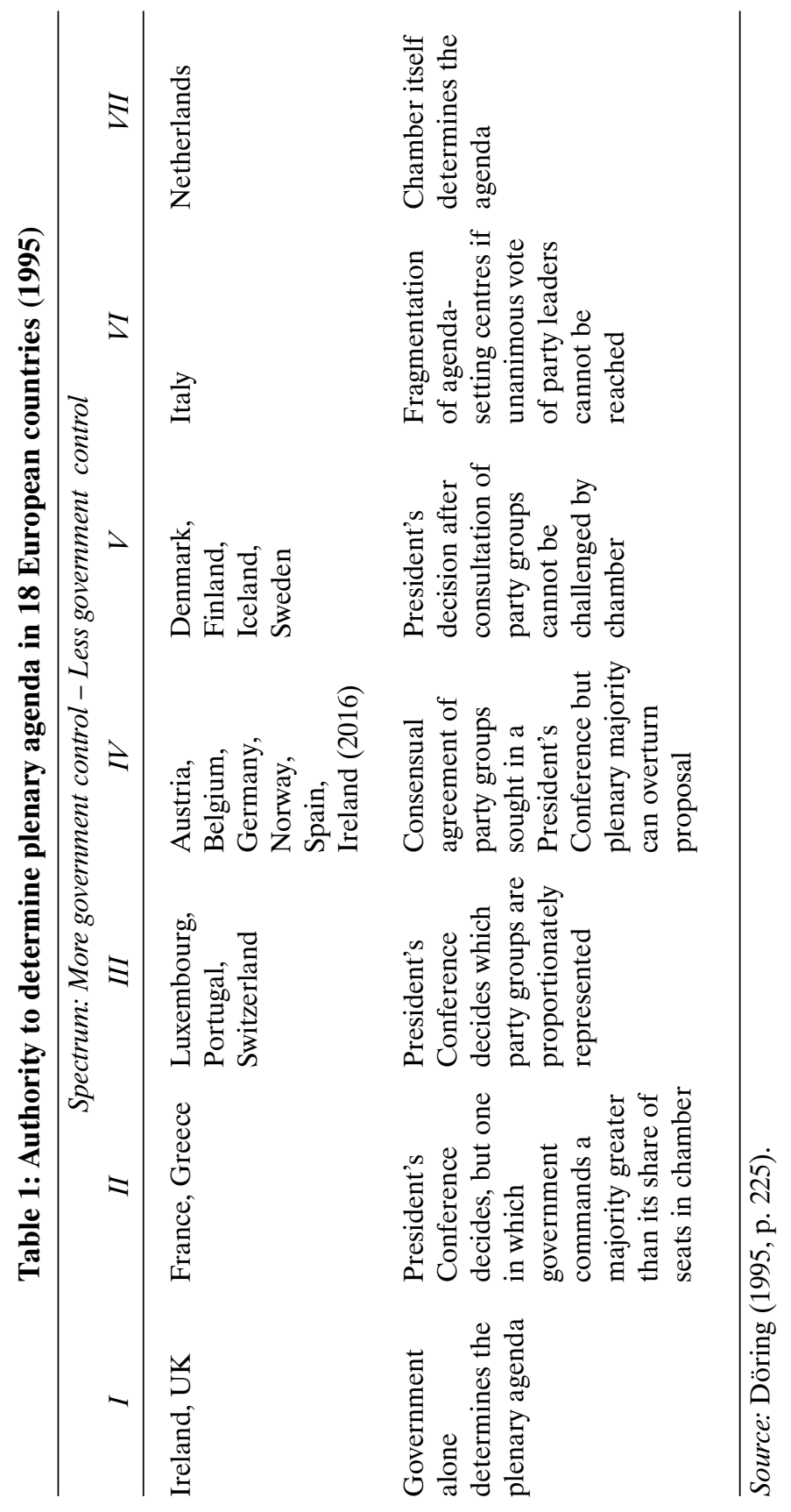


Agenda control is also determined through authority to restrict time for debate and impose allocation of time motions. This can include the right to restrict the time during which a proposal can be discussed before a decision is taken, which can effectively make it difficult to discuss amendments proposed by the opposition (Rasch, 2014, p. 463; Tsebelis \& Rasch, 2011). Döring (1995) ranked parliaments on the same spectrum depending on the extent to which the government possesses this instrument. At one end, where agenda control is centralised, the government may use its simple majority to unilaterally place limits on the time for a debate, including ruling that all stages of the legislative process for a bill be taken together. Where agenda control is less centralised, any limits on the time for debate must be agreed in advance according to a set of rules. Where the agenda setter has least control and is therefore decentralised, there is no such instrument available (Table 2).

In the 1995 analysis the Dáil was classified in the category with most government control for this instrument, as can be seen from Table 2.

Table 2: Authority to impose allocation of time motion

\begin{tabular}{|c|c|c|}
\hline \multicolumn{3}{|c|}{ Spectrum: More government control - Less government control } \\
\hline$I$ & II & III \\
\hline $\begin{array}{l}\text { France, Greece, } \\
\text { Ireland, UK }\end{array}$ & $\begin{array}{l}\text { Austria, Belgium, } \\
\text { Denmark, Germany, } \\
\text { Iceland, Italy, } \\
\text { Luxembourg, Norway, } \\
\text { Portugal, Spain, } \\
\text { Switzerland }\end{array}$ & $\begin{array}{l}\text { Finland, Netherlands, } \\
\text { Sweden, Ireland ( } 2016 \text {, } \\
\text { with further change } \\
\text { possible) }\end{array}$ \\
\hline $\begin{array}{l}\text { Government may use its } \\
\text { simple majority to } \\
\text { unilaterally place limits } \\
\text { on time for a debate, } \\
\text { including an order that } \\
\text { all stages and the final } \\
\text { vote are taken at one } \\
\text { time; there are no rules } \\
\text { (e.g. minimum time } \\
\text { between stages) to } \\
\text { prevent this }\end{array}$ & $\begin{array}{l}\text { Limitation of the time } \\
\text { for debate may be } \\
\text { agreed in advance } \\
\text { according to a set of } \\
\text { rules but may not be } \\
\text { unilaterally imposed, } \\
\text { e.g. limitation of time } \\
\text { may require a } \\
\text { supermajority or mutual } \\
\text { agreement between } \\
\text { parties in the } \\
\text { President's Conference }\end{array}$ & $\begin{array}{l}\text { No rule which allows } \\
\text { closure or advance } \\
\text { limitation of debate; if a } \\
\text { bill is urgent the } \\
\text { government must use } \\
\text { the normal procedures }\end{array}$ \\
\hline
\end{tabular}

Source: Döring (1995, p. 240-1). 
In the Dáil the government has controlled the agenda by using its majority to guillotine debates at will, a point which became especially controversial during the thirty-first Dáil term.

The second item on the Tsebelis \& Rasch (2011) list is proposal rights and gatekeeping rules. Proposal rights can lie exclusively with the agenda setter: they may be assigned to government and political groups in parliament or to individual members of parliament. A gatekeeping rule effectively restricts the proposal rights of actors other than the agenda setter. Gatekeeping rules have been described as 'a veto without an override provision' (Krehbiel, 2004, p. 116).

Proposal rights for actors other than the government may be limited in a formal way. For example, the number of proposals which they may place on the agenda may be restricted, as well as the time slots available to have them considered by parliament. Or the right to propose certain types of bills (e.g. a bill to amend the Constitution, a bill involving the appropriation of public funds or imposition of taxation) may be restricted by rules of procedure. It must also be remembered that while proposal rights may be assigned to governments and groups, government often enjoys a de facto monopoly of policy initiation, in part because it has the civil service at its disposal (Tsebelis \& Rasch, 2011). Even if members of parliament have extensive rights of proposal, they are limited by resource and capacity constraints (e.g. little or no access to legal advice, policy advice or legal drafting). Returning to Döring's (1995) classification system, high level of government control in this instance would mean that the government has exclusive, or close to exclusive, rights to propose legislation while the opposite end of the spectrum would see opposition and government parties have equal proposal rights.

Proceeding to item three, closed and restrictive rules on the right to propose amendments, under fully closed rules, no actor other than the proponent may table amendments to a bill: i.e. government asks parliament to accept or reject (but not to propose amendments to) a bill. Restrictive rules permit actors to propose amendments but limit the type or timing of amendments which are permissible. There are many examples of closed and restrictive rules in the Dáil. Perhaps the best example of a closed rule is that, contrary to the legislative process in most parliaments, the Dáil must take a yes/no vote on the general principles of a bill before that bill is examined in detail by committee and before any amendments may be proposed. This is considered to close off, or at least to reduce, the possibility of any substantial changes being made by parliament (Döring, 1995). 
Item four addresses expansive and sequencing rules. These permit the agenda setter to propose amendments that are prohibited to other actors or to propose amendments at times when others may not do so. It is argued that expansive rules which give the government the power to introduce late amendments enable governments to maintain control over their bills. A clear example of this practice in the Dáil procedures is the rule which forbids opposition members from proposing legislation or proposing amendments to legislation which incur a charge. Specifically, under Dáil standing orders, a bill which involves 'the appropriation of revenue or other public moneys, other than incidental expenses' may not be initiated by any member, save a member of government. Where the 'appropriation of revenue or other public money' is involved, including 'incidental expenses', the committee stage of the bill must not be taken, in accordance with Dáil Standing Order 179(2) of 2016, unless the purpose of the appropriation has been recommended to the Dáil by a message from the government, and the text of any message must be printed on the Order Paper. Further, under Dáil Standing Order 179(3) of 2016, 'an amendment to a Bill which could have the effect of imposing or increasing a charge upon the revenue may only be moved by a Member of the Government or a Minister of State'. And under Dáil Standing Order 180 of 2016, a motion to grant money for the public service can be initiated only by a member of the government. Furthermore, any motion to grant money must be decided without amendment.

Finally, item five is concerned with vote counting and voting order rules. Voting procedures determine how votes are cast and the requirements for winning a vote (a simple or an absolute majority), as well as the sequencing of votes where more than one vote is necessary for a decision to be made.

Parliamentary control can operate via various institutional mechanisms. The most widely used are prime minister's question time (Müller \& Sieberer, 2014, p. 323) and investigations undertaken by parliamentary committees. Little empirical or conceptual work has examined how variation in the rules around parliamentary questions strengthen or weaken parliament's control of government - i.e. its ability to monitor and get answers about the executive's policy and how it is implementing its legislative and policy programme (Müller \& Sieberer, 2014) - but it is agreed that these rules are important, especially in how they shape the behaviour of legislators (Hug, 2010; Hug et al., 2015). Müller \& Sieberer (2014) suggest that, provided both oral and written questions are permitted, the effectiveness of 
questions as an instrument of control depends on whether the rules impose constraints on the type and subject of a question, and whether there are means to enforce good-quality answers to parliamentary questions. As the speaker is generally assigned a role in ensuring the latter, rules about how the speaker is selected and the extent to which he/she sees his/her position as neutral or as an agent of the government, and/or has genuine power to force ministers to answer questions, become important. Prior to reforms, Dáil standing orders privileged the government with many of these instruments of agendasetting power, again reinforcing the government's dominance within agenda-setting rules.

Using the research literature on parliaments to benchmark the Dáil gives a clear indication of the extent of the centralisation of parliament in Ireland. Evaluating the Dáil along the five dimensions of agenda setting demonstrates that the 'puny parliament' description was not unwarranted. The benchmarking also serves to highlight the validity of the arguments about Dáil reform which were articulated in the lead up to the 2011 election and to a lesser extent at the 2016 election. There was an overwhelming case for Dáil reform.

\section{Why did political reform happen at last?}

If there was an overwhelming case for Dáil reform in 2011, it was hardly new. The design and operation of the Dáil were heavily influenced by the British Westminster model, as were other anglophone parliaments such as those in Canada and Australia. While these countries, and indeed Britain itself, have seen their parliamentary practices evolve, the Dáil retained many originally nineteenth century rules and practices well into the twenty-first century. The epithet 'puny parliament' was given to the Dáil by Basil Chubb (1992), but indeed almost all analyses of parliament in Ireland highlight its dominance by the executive and associated weak capacity for oversight and poor opportunities for legislators to influence the law-making process.

There are institutional explanations for executive dominance. Government and parliament are fused, with ministers simultaneously serving as TDs. The state's role has grown in breadth and complexity, which makes parliament's task of holding the government to account more difficult. Furthermore, the presence of highly disciplined parties in parliament, where deviation from the party line is punished, reduces the likelihood of open debate and robust challenging of policy positions advocated by the government. 
Importantly, it has been generally agreed among political scientists and commentators, including many TDs, that the Dáil is weaker vis-àvis the executive than is the case in other Westminster-style parliaments, and certainly than is the case in the more consensusseeking parliaments of Europe. Garritzmann (2017) demonstrates that the opposition has a very weak capacity to control the government, although the Dáil scores better for the opposition's ability to present alternative policies. It is accepted that parliamentary procedure - meaning the set of rules and institutions which govern the interaction between the legislature and the executive, and which outline how parliament goes about its business - contributes significantly to this weakness. The received wisdom that parliamentary procedure lies at the core of the problem of executive dominance in Ireland is an important point. Cox \& McCubbins $(1997 ; 2005)$ argue that procedural rules usually reflect the interests of the governing majority, which in essence means that the weakness of the Dáil is a function of the rules on how it conducts its own business. Parliamentary procedure has facilitated almost exclusive government control of the agenda, limiting the impact of parliament on policy outcomes, the extent of legislative scrutiny, and the extent to which the legislature can control the executive and hold it to account. In his assessment of procedures in the Dáil, Caffrey (2010, p. 257) argues that 'standing orders have changed only very gradually and often in an unstructured way'. This sets the Dáil apart from many other parliaments around the world. In contrast, Sieberer et al. (2011, p. 948) concluded that 'parliamentary rules are changed frequently and massively'. This raises the important question of what changed in the lead-up to the thirty-first Dáil to shift the interests of the governing majority towards long-avoided but much-needed reform.

There were concerns about the functioning of Ireland's political institutions and the nature of electoral politics long before the economic crisis developed in 2008, but to an extent economic prosperity kept these worries at bay. Political reform became an important part of the debate in the lead-up to the 2011 general election. It was the first time that political reform made it onto the agenda in a substantive manner. There was a shared narrative on the problems which beset the political system. These included cronyism, localism, sub-optimal decision-making and executive dominance. Reports on the origins of the economic crisis by both domestic and international experts cited problems such as the small and overlapping nature of political elites and, stemming from this, a tendency for 
groupthink, weak political institutions and poor policy oversight to emerge (Regling \& Watson, 2010; TASC, 2010).

All of the political parties included sections on political reform in their manifestos and some produced separate, more extensive texts, which were published before the election was formally called (Suiter \& Farrell, 2011). There was considerable mobilisation on the issue, with civil society groups, business leaders, academics and the media putting forward reform plans. The essential focus of all proposals was to strengthen political institutions and transform electoral politics. Dáil reform was a key component of all of the manifestos.

Manifestos are important documents and often form the basis of the programme for government. Commitments which are included in the programme for government have a high chance of being implemented (Costello et al., 2016). The 2011 programme for government included a detailed list of political reforms, and Dáil reform was included as a discrete category, although, as can be seen from Table 3, several included items related to the role of parliament.

Table 3: Political reform legislative commitments summary 2011 programme for government

Section

Number of

commitments

We will ensure our government is seen to be held to account 7 We will overhaul the way politics and government work 20

Showing leadership

Dáil reform 14

More effective financial scrutiny

26

The national parliament and the European Union 11

Reforming local government

10

Total

91

Dáil reform had comprehensively become part of the political agenda. But there were significant political impediments to reform in 2011. Though it spoke of a 'democratic revolution', the new Fine Gael/Labour government's massive majority, coupled with the difficult agenda of cuts that was to a large extent dictated by the troika, meant that it was disinclined to cede much power to parliament. If anything, power became more centralised, as the Economic Management Council took some power from cabinet (O'Malley \& Martin, 2017) and the government was more willing to use guillotine powers than its predecessors had been (see McGee, 2010). However, Dáil reform was 
considered by the Constitutional Convention and a number of the proposals recommended by the convention were included in the package of reform measures progressed by the government in early 2016. These reforms had been in planning for some time and included direct election of the Ceann Comhairle, use of the d'Hondt electoral mechanism for appointment of committee chairs and agreement by the Taoiseach to appear before the working group of committee chairs.

Dáil reform was again on the agenda after the February 2016 election, but on this occasion it was the fragmented outcome of the election and the expected establishment of a minority government which meant that business as usual - executive dominance - was neither possible nor practical. Even with no rule changes, the position of the government vis-à-vis the Dáil was considerably weakened. The opposition now wanted to institutionalise parliamentary reform in advance of government formation negotiations (see O'Malley, 2016). Reform moved from being an academic discussion to an immediate necessity. This development accords with much research which shows that increasing fragmentation of politics and ideological polarisation are associated with more decentralised agenda control (Diermeier \& Vlaicu, 2011; Diermeier et al., 2015). The thirty-second Dáil established a Sub-Committee on Dáil Reform, chaired by the Ceann Comhairle, which, on the basis of submissions received from all parties, groups and some individual TDs, discussed and agreed fundamental reforms to standing orders, which were subsequently approved by the Dáil.

In all, fourteen deputies made individual submissions while eight submissions were received from parties or groups and one by a private citizen. A further five submissions were received in April, after the initial deadline. Thus, in total, twenty-three submissions were received. Following two initial meetings, an interim report was laid before the Dáil and interim statements taken. Some twenty members contributed to the debate. ${ }^{1}$ A further eight meetings resulted in the draft final report and the sub-committee also agreed to review the operation of the new proposals some six and twelve months later. The sub-committee continues to meet regularly and, in effect, reviews the operation of standing orders on an ongoing basis.

1 The submissions and papers received by the sub-committee are available on www.oireachtas.ie. See Sub-Committee on Dáil Reform (2016) for full report. 


\section{The reforms}

There is considerable consensus in the literature on parliament in Ireland that government control of the agenda is a major contributory factor to executive dominance. Until 2016 the effective direct appointment of the Ceann Comhairle by the government underpinned the strong sense that decisions taken by the chair were not always impartial and independent of government. The benchmark exercise in this article highlighted the specific ways in which Dáil procedures and practices undermine the independence of the Dáil as parliament. In this section we review the reforms which were implemented during the terms of the thirty-first and thirty-second Dáileanna, focusing again on the position of the Ceann Comhairle and on agenda-setting powers and procedures.

Seán Ó Fearghaíl became the first person to be elected into the position of Ceann Comhairle by secret ballot when the thirty-second Dáil met. There were five candidates for the post. The new rules agreed prior to the election required that candidates had to be members of the Dáil and be nominated by at least seven TDs. Each TD could nominate just one candidate. The election took place by secret ballot, an important feature of the new change as it ensured that parliamentarians had more scope to select a chair of their preference. This is especially important in the Dáil, where party discipline is high. Indeed, in contrast to the initially open position advocated by many of the parties when the secret ballot process for Ceann Comhairle was being discussed in January 2016, some political parties - Fianna Fáil and Sinn Féin - operated an internal pre-selection process to choose a party candidate for the election, deviating somewhat from the spirit of the reform.

Direct election of the Ceann Comhairle is crucial in a number of ways. It ensures that the candidate elected is acceptable to a majority of TDs and the election also removes the postholder from the direct orbit of government. Cinn Comhairlí have long been criticised for being 'creatures of the government' by virtue of their direct appointment by the Taoiseach. Breaking that link was an important step in enhancing the independence and autonomy of the Ceann Comhairle. Interviews conducted for this article suggest that the reform expectations have been met, and both government and opposition TDs agree that the Ceann Comhairle is seen as independent of government and carrying greater authority. An important interacting point though is that Seán Ó Fearghaíl is a 
member of Fianna Fáil and not drawn from the governing party, a feature which is seen as enhancing his independence.

Prior to the 2016 Dáil reform, the Taoiseach had the exclusive right to set the plenary agenda, a right generally implemented on his behalf by the government party whip(s). Opposition parties could only influence the agenda through their proposals for private members' time (which had limited time slots that could be taken over by government business on announcement by the Taoiseach).

One of the most fundamental reforms agreed by the thirty-second Dáil was to remove the Taoiseach's prerogative to set the Dáil's agenda. A Business Committee was established that is representative of all of the groups in parliament, and it has been given responsibility for agreeing weekly agendas and planning sessional ones. Under the revised standing orders, the Business Committee, which is chaired by the Ceann Comhairle, meets to agree and publish an agenda for the following week. At the meeting the government determines the business for government time, the business for opposition groups and the business to be taken in private members' time (the time for which has been substantially increased). The committee initially agreed a $60 / 40$ split of time for government/opposition business. This time split is coming under strain as the government has found it has limited time for its own legislation, and it would be unlikely to survive a majority government with significantly more legislation being brought to the Houses.

The Business Committee aims to make decisions by consensus; however, if the Ceann Comhairle judges that there is no consensus, he/she may call for a vote. A rapporteur from the Business Committee announces the business at the 'Order of Business' on Tuesdays and the House decides on the proposed agenda for each day. Where urgent items arise, the government chief whip may propose to the House that this business be taken. Using Döring's categorisation system, the Irish parliament would now sit firmly in category IV. This is a significant movement along the spectrum (presented in Table 1). While standing orders give the Ceann Comhairle a far greater role in setting the agenda and the right to decide if there is consensus in the Business Committee, it does not give him/her the right to make a decision in the event that parties cannot agree (as is the case, for example, in Finland). The establishment of the Business Committee has created transparency around the legislative planning process, by bringing it into parliament and involving all sides of parliament in the process. 
The ability to restrict discussion time for bills is also an important aspect of scheduling. In the bulk of Europe's parliaments there has to be some form of cross-party consensus before a guillotine can be applied. In spite of its intentions to reduce the use of the guillotine, the 2011-16 government continued to use it extensively. In assigning the legislative agenda to the Business Committee, including what legislation is considered and how and when it is considered, the opportunities for unilaterally imposing a guillotine have been reduced in the thirty-second Dáil. In its report, the Sub-Committee on Dáil Reform (2016) announced that gaps of two weeks should be required between stages, and that committee and report stages could not be held on the same day unless otherwise agreed (p. 8 - i.e. agreed through the Business Committee). As such, the Business Committee is tasked with programming legislation, although this process is at an early stage in the Houses of the Oireachtas and is under discussion with the committee of chairs. Standing orders still give the government chief whip the right to propose the taking of urgent business (which could potentially be a bill), notwithstanding the agenda agreed by the Business Committee. The approval of the chamber is required, however. Returning to Döring's (1995) classification system, the Dáil would also move along the spectrum and, specifically in relation to the classifications presented in Table 2, the Dáil would now be included in category III. Thus, Dáil reforms have had the impact of reducing government control.

In relation to proposal rights and gatekeeping rules, prior to the 2016 reforms, the Dáil would have been located in the middle of the spectrum as parties or groups with a minimum of seven members were in a position to table legislation but with the limitation that only one item per order paper was allowed. There were no restrictions on the proposal rights of the government. Under the package of reforms agreed at the start of the thirty-second Dáil, the number of Dáil deputies required to form a parliamentary group was reduced to five and the limit on the number of technical groups was removed. There was (and continues to be) some dispute about this, as the larger opposition parties feel they are unfairly treated in the time allocations.

The combination of these changes means that there are more groups empowered to propose legislation. Furthermore, procedures incentivise the introduction of private members' bills (PMBs) over motions, as bills allow deputies more time. At the time of writing, there were 114 PMBs before the House, compared to 28 government bills. Resourcing changes mean that all technical groups now have 
access to administrative supports similar to those available to political parties, and this measure should address some of the technical challenges which non-aligned deputies faced in engaging effectively with the legislative process. During the thirty-second Dáil it was privately acknowledged that some PMBs fell short of the standard expected of bills in a parliament. Poorly designed PMBs were crowding out those good ones with the potential of garnering the support of the Oireachtas. It was agreed that some form of legal and parliamentary support would be needed. To that end, a legal advisory service will be set up to assist deputies with drafting legislation and give alternative legal advice to that offered by the government, coming from the Attorney General. There is also a view held in some quarters that the new arrangements for PMBs favour smaller, more radical parties as they have more opportunities to bring forward PMBs and their bills receive more media coverage than the more prosaic matters often considered by the centrist parties. ${ }^{2}$

Turning to closed and restrictive rules, the principles of a bill are agreed in plenary session and subsequent amendments proposed cannot be contrary to the general principles of the bill. These rules remain in place, but pre-legislative scrutiny was introduced during the thirty-first Dáil whereby ministers were obliged to publish the general schemes of bills, and this reduced the impact of the closed rule. For PMBs that pass second stage, a new scrutiny stage has been introduced under Dáil Standing Order 141 of 2016; this allows a committee to scrutinise the bill and report back to the Dáil before the formal lineby-line committee stage commences.

In relation to expansive rules and sequencing rules, the Dáil falls on the strict or centralised end of the spectrum for this category. Thus, very little has changed as a result of recent reforms. In the specific case where a bill incurs a charge on the state, only members of the government may propose amendments (minister or minister for state). While the financial initiative of government is protected in the Constitution, ${ }^{3}$ the question of relaxing the restrictions on the right of

2 Information provided in interviews with staff and members of the Houses of the Oireachtas.

3 Article 17.2 restricts the Dáil's right to pass resolutions or laws involving the expenditure of public monies without a message authorising it from the government (money message). A large majority of bills require this money message, which is usually granted, though in the current Dáil it was denied to a bill on judicial appointments, as an effective government veto. Articles 21 and 22 require that money bills may only be initiated in the Dáil and give the Ceann Comhairle the role of certifying a money bill. 
ordinary members to introduce amendments and bills ${ }^{4}$ incurring a charge was considered by the Committee on Arrangements for Budgetary Scrutiny (a temporary committee established to report on how the Committee on Budgetary Scrutiny should engage in budgetary scrutiny). There are procedural options for relaxing the restrictions (within the constitutional framework), which would provide space to discuss amendments ruled out of order. There may also be the possibility of allowing non-government bills which incur a charge to proceed beyond committee stage, but not to pass without a money message, a procedure adopted by the New Zealand parliament in 1996.5 The Sub-Committee on Dáil Reform had not proposed substantial procedural changes at the time of writing.

While the right of financial initiative remains with the government, it has agreed to release information earlier to enable enhanced scrutiny of the budgetary process by the newly established Committee on Budgetary Oversight. ${ }^{6}$ This is populated by the finance spokespersons of the parties and is expected to deal with spending decisions ex ante, where the PAC deals with them ex post. It will be dependent on the imminent formation of a Parliamentary Budget Office for technical support.

There was also an attempt to separate committee time and plenary time, with distinct slots for each. This has already come under strain, as certain debates were scheduled for longer than there was time available, and so the Dáil plenary session had to schedule debates for what was meant to be committee time. Reforms of vote counting and vote order have also been agreed in the Dáil. Votes are now clustered into a single session every week. This reform was influenced by the need to allocate specific time for committee business and to eliminate the requirement of TDs to leave committees to vote, which was a regular part of the practice in previous Dáileanna. The new block voting and electronic voting system allows formal abstentions to be recorded, which also required a change to the standing orders. Block voting also means that traditional late-night votes no longer occur,

\footnotetext{
${ }^{4}$ Ordinary members may not propose a bill involving appropriation of revenue or other public money, other than incidental expenses, and if the bill does appropriate incidental expenses, it cannot go to committee stage without a money message.

${ }^{5}$ New Zealand parliament, Standing Orders 326-30. The procedure is referred to as the financial veto.

${ }^{6}$ For example, SPU (Stability Programme Update) and Spring Economic Statement published earlier in draft to facilitate debate, and circulation of tax strategy papers in July prior to the formal presentation of the budget in October.
} 
removing the need for TDs to attend late at night, leading some to complain that Leinster House has lost some of its atmosphere.

\section{Conclusion - Institutionalised or temporary power?}

The reforms made in the thirty-first and thirty-second Dáileanna represent the most substantial changes to the operation of the Dáil since it was formed. These changes shift Ireland substantially on the scale of government control of the parliament (Farrell \& Suiter, 2016). In particular, the election of the Ceann Comhairle by secret ballot, the creation of the Business Committee, pre-legislative scrutiny and the allocation of committee chairs on the basis of proportionality can strengthen the parliament. Using existing legislative benchmarks, it is clear that there have been important improvements and the Dáil is now a less centralised parliament, especially in relation to its ability to determine its own agenda. Another notable change is the absence of rows on the floor of the House. Many of these had been caused by disputes over technicalities in the procedures, often leading to members being ordered to leave the chamber.

However, at the first anniversary of the election of the thirty-second Dáil, many political commentators lamented that the Dáil was working less well than before. The consensual system meant that the Dáil was slower in coming to agreement on issues. Critics pointed in particular to the low number of Acts passed in 2016. Notwithstanding the fact that the number of Acts passed is always low in an election year, 2016's number was particularly low. In these commentators' minds, this measure demonstrated the failure of 'New Politics' (as the new arrangements came to be known). Their criticisms conflated two important changes evident in 2016: a minority government, unable to expect to command a majority in the Dáil, and significant reform of Dáil procedures.

There are problems with the new rules; for instance, they give too much time to the opposition's business and do not allow government enough time for the opposition to oversee and monitor government legislation. But it is incorrect to blame the rules for the requirement by the government to engage in extensive cross-party discussion on legislation to ensure it is progressed. Rather, this is a function of the minority arithmetic and, no doubt, caution on the part of ministers in bringing bills to the Oireachtas until they have a reasonable prospect of progression. Greater discussion and evaluation of legislation in the Dáil had long been petitioned for. It remains to be seen whether this 
is resulting in the slowing down and dilution of necessary reforms or delivering more considered and effective governance. To make a real assessment of the impact of the rule changes, we will need to see how the new Dáil procedures work under coalition governments which have a majority.

\section{References}

Caffrey, R. (2010). Procedure in the Dail. In M. MacCarthaigh \& M. Manning (Eds), The Houses of the Oireachtas: Parliament in Ireland (pp. 257-84). Dublin: Institute of Public Administration.

Chubb, B. (1992). The government and politics of Ireland (3rd ed.). Harlow: Longman.

Costello, R., O'Neill, P., \& Thomson, R. (2016). The fulfilment of election pledges by the outgoing governments. In M. Gallagher \& M. Marsh (Eds), How Ireland voted 2016: The election that nobody won. London: Palgrave.

Cox, G. C., \& McCubbins, M. D. (1997). Toward a theory of legislative rules changes: Assessing Schickler and Rich's evidence. American Journal of Political Science, 41 (4), 1,376-86.

Cox, G. C., \& McCubbins, M. D. (2005). Setting the agenda: Responsible party government in the US House of Representatives. New York: Cambridge University Press.

Diermeier, D., Prato, C., \& Vlaicu, R. (2015). Procedural change in majoritarian organizations. American Journal of Political Science, 59 (4), $866-79$.

Diermeier, D., \& Vlaicu, R. (2011). Parties, coalitions and the internal organization of legislatures. American Political Science Review, 105 (2), $359-80$.

Döring, H. (Ed.) (1995). Parliaments and majority rule in Western Europe. NYC: St Martin's Press.

Farrell, D., \& Suiter, J. (2016). The election in context. In M. Gallagher \& M. Marsh (Eds), How Ireland voted 2016: The election that nobody won. London: Palgrave.

Garritzmann, J. L. (2017). How much power do oppositions have? Comparing the opportunity structures of parliamentary oppositions in 21 democracies. Journal of Legislative Studies, 23, 1-30.

Hug, S. (2010). Selection effects in roll call votes. British Journal of Political Science, 46 (3), 263-77.

Hug, S., Wegmann, S., \& Wuest, R. (2015). Parliamentary voting procedures in comparison. West European Politics, 38 (5), 940-68.

Koss, M. (2015). The origins of parliamentary agenda control: A comparative process tracing analysis. West European Politics, 38 (5), 1,062-85.

Krehbiel, K. (1992). Information and legislative organization. Michigan: University of Michigan Press. 
Krehbiel, K. (2004). Legislative organisations. Journal of Economic Perspectives, 18, 113-28.

MacCarthaigh, M., \& Manning, M. (Eds) (2010). The Houses of the Oireachtas: Parliament in Ireland. Dublin: Institute of Public Administration.

McGee, H. (2010). Chief Whip admits government performance on Dáil reforms deplorable. The Irish Times.

Müller, W. C., \& Sieberer, U. (2014). Procedure and rules in legislatures. In S. Martin, T. Saalfeld \& K. Strøm (Eds), The Oxford handbook of legislative studies. Oxford: Oxford University Press.

O’Malley, E. (2011). Permanent revolution: A political system capable of renewal. In E. Burke \& R. Lyons (Eds), Next generation Ireland. Dublin: Blackhall Publishing.

O’Malley, E. (2016). 70 Days: Government formation in 2016. In M. Gallagher \& M. Marsh (Eds), How Ireland voted 2016: The election that nobody won. London: Palgrave.

O'Malley, E., \& S. Martin. (2017). The government and the Taoiseach. In J. Coakley \& M. Gallagher (Eds), Politics in the Republic of Ireland (6th ed.). London: Routledge.

Rasch, B. E. (2014). Institutional foundations of legislative agenda-setting. In S. Martin, T. Saalfeld \& K. Strøm (Eds), The Oxford handbook of legislative studies. Oxford: Oxford University Press.

Regling, K., \& Watson, M. (2010). A preliminary report on the sources of Ireland's banking crisis. Dublin: Government Publications Office.

Sieberer, U., Müller, W. C., \& Heller, M. I. (2011). Reforming the rules of the parliamentary game: Measuring and explaining changes in parliamentary rules in Austria, Germany and Switzerland 1945-2010. West European Politics, 34 (5), 948-75.

Suiter, J., \& Farrell, D. M. (2011). The parties' manifestos. In M. Gallagher \& M. Marsh, How Ireland voted 2011: The full story of Ireland's earthquake election. (pp. 29-46). London: Palgrave Macmillan.

Sub-Committee on Dáil Reform. (2016). Final report of the Sub-Committee on Dáil Reform. Retrieved from http://opac.oireachtas.ie/AWData/Library3/ Final_Report_of_the_Sub-Committee_on_Dail_Reform_140623.pdf [23 March 2017].

TASC. (2010). Mapping the golden circle. Dublin: TASC.

Tsebelis, G., \& Rasch, B. E. (2011). Governments and legislative agenda setting. An introduction. In B. E. Rasch \& G. Tsebelis (Eds), The role of governments in legislative agenda setting (pp. 1-20.). London \& New York: Routledge. 